\title{
Correlations between delayed fluorescence of chlorophyll, metabolism and yield of plants. I. Influence of fertilizers on correlations
}

\section{Armen B. Avagyan}

Research and Industry Center of Photosynthesising Organisms, Feed Additives and Physiologically Active Compounds, Yerevan, Armenia; armin.av@hotmail.com

Received 7 April 2010; revised 26 April 2010; accepted 8 May, 2010.

\begin{abstract}
The increase of the potash fertilizer dose induced a raise in efficiency influence of the nitrogen fertilizer, optimisation of phosphorous fertilizer effect, enhancement of leaf protein production, expansion of assimilating surface and yield growth. In the period of yield formation, the parameters of delayed fluorescence of chlorophyll (DF) of leaf wholly corresponded with key factors that had a dramatic influence on the effectiveness of yield formation. The maximum level of DF amplitude mostly depended on the activity of nitrogen metabolism and presumably on active PSIl concentration changes per square unit. Half-decay time of this amplitude was predominantly identified by the level of carbohydrate metabolism in the overall plant system, including the quantity of its products and, therefore, mostly by correspondence with yield. This is a biological base triggering the use of DF parameters for system analyses of plant production process.
\end{abstract}

Keywords: Delayed Fluorescence of Chlorophyll; Metabolism; Nitrogen; Phosphorus and Potash Fertilizers; Moisture; Poisonous; Yield

\section{INTRODUCTION}

Plant growth is affected by numerous environmental factors. Therefore, it is difficult to predict the amount of yield, without system analyses of interaction among all key components of crop yield formation. Finding general relationship in the complex system of the plant also required selection of appropriate key objects. Our choice was PSII, which is the main producer of the DF (the level of PSI DF is several times lower [1]). DF transients have been shown to be driven by many mechanisms, including electrical and $\mathrm{pH}$ gradients [2], acceptor availability, donor availability [3], and redox state of the oxygen-evolving system $[4,5]$. The DF induction curve, registered in a several-minute period, encompasses two major phases - a fast one taking place in the first second of induction, and a slow one, that can last for minutes. Each phase is shaped by several processes running at the same time [4,5]. When applying the phosphoroscopebased method of registration, the fast phase I observed as maximum intensity of leaf DF curve. Many authors attribute this initial phase to the light induced changes of the electrical potential and proton gradient across the thylakoid membrane, depending from the state of the PSII reaction center, which result manifests in the decrease the amount of activation energy necessary for the back reaction between $\mathrm{QA}^{-}$and $\mathrm{Z}^{+}[2,4,6]$ as well as may depend from quantity of oxidized QA (Figure 1).

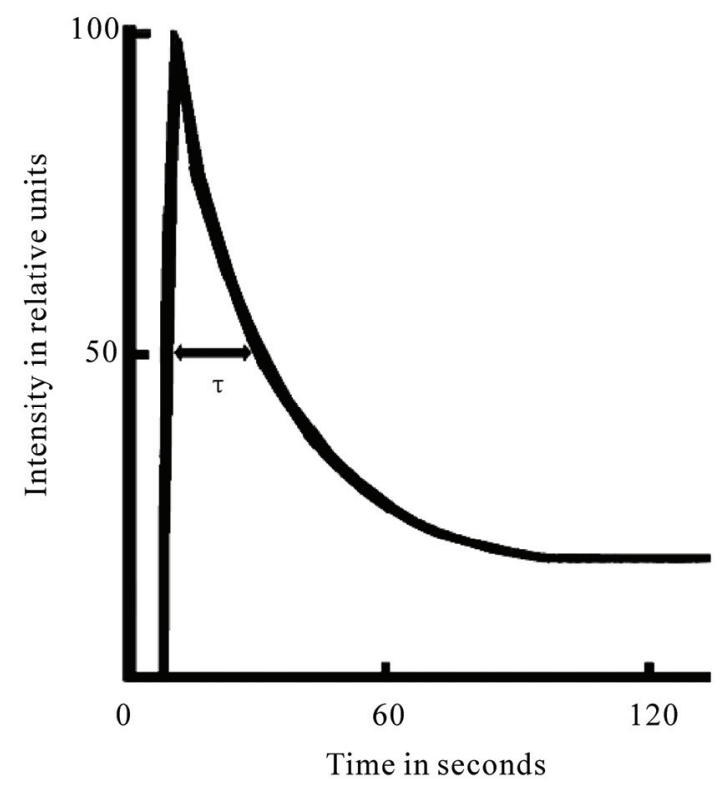

Figure 1. Induction curve of delayed fluorescence of chlorophyll. 
Previously, it assumed that kinetics of fast phase further decay depend from the photosynthetic dark processes intensity [4-6]. This decay of induction curve induced the membrane energisation decreasing as result of cation efflux from thylakoids. These are a biological base triggering the use of these DF parameters in physiological research. The interest of using the parameters of DF for the diagnosis of plants state identified as the possibility of their fast measurements on intact objects by the use of comparatively simple and accessible equipment. Therefore, our goal was research the correspondence of DF parameters, metabolism and yield changes of plants in order of the use of these parameters for the system analyses of production process of field plants.

\section{MATERIALS AND METHODS}

\subsection{Plant Material and Experimental Design}

The tomato (Lycopersicum esculentum) variety Nver seedling and the potato (Solanum tuberosum) variety Pirmunes were planted on May 30 and March 30, respectively, in hot and draughty conditions of loamy clay soils of Ararat Valley, Armenia. The sprouts of pea (Pisum sativum) variety Pobeditel were transferred into solutions of distilled water after seeds germination $(24 \mathrm{~h}$ up to $2-3 \mathrm{~cm}$ rootlets) and grown at temperature of $25^{\circ} \mathrm{C}$, photosynthesis photon flux density of $605 \mu \mathrm{mol} \mathrm{m} / \mathrm{s}$ and a photoperiod of $16 / 8 \mathrm{~h}$. The experiment with pea performed in six replications.

The tomato sprouts planted in three replications on an each field plot of $91 \mathrm{~m}^{2}$. A part of nitrogen at dose of $\mathrm{N}_{30}$ (in $\mathrm{kg} / \mathrm{ha}$ ) and a full dose of phosphoric and potash fertilizers were added to the soil during the pre-sowing cultivation. The other parts of nitrogen fertilizer added twice on May 17 and June 13. For the $\mathrm{N}_{0} \mathrm{P}_{0} \mathrm{~K}_{0}$ variant, the fertilizers not added to the soil.

The potato planted in four replications on each field plot of $50 \mathrm{~m}^{2}$. During experiment of potato, the average air temperature was at $26^{\circ} \mathrm{C}$, and the maximum air temperature was at $33.6^{\circ} \mathrm{C}$. The potato plants were watered only on June 25 (on June 19 the soil humidity was $16.9 \%$, June $24-14.0 \%$, June $26-21.4 \%$, July $8-14.3 \%$ and 15 $-12.2 \%)$.

\subsection{Measurement and Sample Protocol}

The yield of plants obtained per plant and for each plot. The analysis of chemical compounds quantity was performed by the use of standard methods in air-dry samples by methods of Ginsburg for leaves and Maslova $\left(\mathrm{K}_{2} \mathrm{O}\right)$ and Arrhenius $\left(\mathrm{P}_{2} \mathrm{O}_{5}\right)$ for soil [7]. The humidity of soil (in the ground layer $0-30 \mathrm{~cm}$ ) and leaves measured through samples drying at $105^{\circ} \mathrm{C}$ and $80^{\circ} \mathrm{C}$, respectively, in oven through 3-4 repetitions. The square of assimilat- ing surface of plants measured by using weighing method and device AAT-5 (Hayasaki Denco Co., Japan) in four repetitions.

The parameters of the leaves DF induction curve were measured from the center of lobes by using a single-disc phosphoroskope (time between excitation and recording of DF was $7 \mathrm{~ms}$ ) at temperature of $22^{\circ} \mathrm{C}$. Exciting light was obtained from a $200 \mathrm{~W}$ glow lamp (KGM-200, provided maximum intensity of modulated visual light at the sample surface of $2000 \mu \mathrm{mol}$ photons $\mathrm{m}^{2} / \mathrm{s}$ ) and photodiode. Each detached-from-leaf lobe incubated about 1.5 hour in the dark between paper sheets at temperature of $4^{\circ} \mathrm{C}$.

The leaf DF parameters and concentration of chemical compounds of tomato leaves measured since fructification phase, per 10 dates. The DF measurements were made with fields leaves detached from 50 tomato plants of each variant for each data of test. The calculation of yield (plot-based weighing method) and concentration of chemical compounds of fruits was carried out on 3 different dates in harvesting stage (July 25, August 6 and 18). The leaf DF parameters and concentration of chemical compounds of potato leaves were measured since bud phase, per 5 dates, concentration of chemical compounds of soil at the end of vegetation.

\subsection{Statistical Analyses}

The replications dates were processed from a purely mathematical standpoint by the use of the Student's and Fisher's exact test, and the standard methods of correlation analyses with 5\% significance level.

\section{RESULTS AND DISCUSSION}

The research of the effects of mineral nutrition on DF parameters was carried out on pea germ fully provided with necessary nutrient components, contained in seed at the early stage of form-building processes. The data shows that in the growing period of germs I increased dramatically by the raise in mineral salts amounts in solution at the initial stage and then it generally fell, compared to salt-free grown plants (Tables 1-3). I reduction correlated with suppression level of germs' vital activity. It is well known that the increase of mineral salt concentration in the nutrient medium stimulates their quantity increase in plants [8]. In the case of an umbalanced heightened amount of separate ions in the nutrient medium, a poisonous effect on plants or unfavourable effect on their yield was observed [8-10]. In the event of addition of mineral salts to nutrition solution, the highest level of poisonous effect was detected for phosphorus anions (Tables 1-3). In complex with $\mathrm{NO}_{3}^{-}$versus $\mathrm{Cl}^{-}$anion cation $\mathrm{K}^{+}$reduced I more rapidly. This was probably based on the obtained capability of plants to 
Table 1. Effect of salt concentration in solution on I of 6-day-old pea and the correlation coefficient between I and salt amount*

\begin{tabular}{|c|c|c|c|c|c|c|c|}
\hline \multirow{2}{*}{$\begin{array}{l}\text { Quantity } \\
\text { in } \mathrm{mM}\end{array}$} & \multicolumn{5}{|c|}{ I in rel. units } & \multirow{2}{*}{ Salt } & \multirow{2}{*}{ Correlation coefficient in rel. units } \\
\hline & $\mathrm{NaCl}$ & $\mathrm{KCl}$ & $\mathrm{KNO}_{3}$ & $\mathrm{KH}_{2} \mathrm{PO}_{4}$ & $\mathrm{Ca}\left(\mathrm{NO}_{3}\right)_{2}$ & & \\
\hline 0 & 100.00 & 100.00 & 100.00 & 100.00 & 100.00 & $\mathrm{NaCl}$ & 0.467 \\
\hline 2 & 93.55 & 119.82 & 105.76 & 97.24 & 101.92 & $\mathrm{KCl}$ & 0.295 \\
\hline 4 & 101.61 & 114.00 & 94.93 & 89.40 & 104.26 & $\mathrm{KNO}_{3}$ & -0.775 \\
\hline 20 & 101.84 & 114.29 & 90.78 & 70.28 & 113.22 & $\mathrm{KH}_{2} \mathrm{PO}_{4}$ & -0.985 \\
\hline $\mathrm{LSD}_{05}$ & 24.17 & 3.96 & 24.67 & 27.67 & 14.31 & $\mathrm{Ca}\left(\mathrm{NO}_{3}\right)_{2}$ & 0.992 \\
\hline
\end{tabular}

*At the significance level of $5 \%$, the critical value of correlation coefficient is 0.950 .

Table 2. Temporal variation of pea I, planted in salt solution.

\begin{tabular}{|c|c|c|c|c|c|c|}
\hline \multirow{3}{*}{$\begin{array}{c}\text { Quantity } \\
\text { in } \mathrm{mM}\end{array}$} & \multicolumn{6}{|c|}{ I in rel. unit } \\
\hline & \multicolumn{3}{|c|}{$\mathrm{Ca}\left(\mathrm{NO}_{3}\right)_{2}$} & \multicolumn{3}{|c|}{$\mathrm{CaCl}_{2}$} \\
\hline & 6 day & 13 day & 20 day & 6 day & 13 day & 20 day \\
\hline 0 & 100.00 & 102.56 & 84.01 & 100.00 & 103.70 & 95.91 \\
\hline 2 & 101.02 & 106.6 & 88.05 & 103.70 & 121.60 & 98.77 \\
\hline 4 & 104.26 & 110.02 & 105.32 & 103.77 & 125.52 & 94.44 \\
\hline 8 & 118.33 & 110.44 & 91.47 & & & \\
\hline 20 & & & & 105.77 & 100.00 & 84.57 \\
\hline $\mathrm{LSD}_{05}$ & 11.10 & 14.07 & 30.39 & 14.72 & 20.53 & 20.88 \\
\hline
\end{tabular}

Table 3. Correlative correspondence between pea DF I and mineral salts concentration*.

\begin{tabular}{cccccccc}
\hline \multirow{2}{*}{$\begin{array}{c}\text { Quantity in } \\
\mathrm{mM}\end{array}$} & \multirow{2}{*}{$\begin{array}{c}\text { Quantity of } \\
\text { repetitions }\end{array}$} & \multicolumn{5}{c}{$\mathrm{Ca}\left(\mathrm{NO}_{3}\right)_{2}$} \\
\cline { 3 - 8 } & & 6 day & 13 day & 20 day & 6 day & 13 day & 20 day \\
\cline { 3 - 8 } & 3 & 0.999 & 0.999 & 0.941 & 0.779 & 0.938 & -0.569 \\
$0 \rightarrow 4$ & 4 & 0.959 & 0.794 & 0.402 & & & $\mathrm{CaCl}_{2}$ \\
$0 \rightarrow 20$ & 4 & & & & 0.817 & -0.530 & -0.973 \\
\hline
\end{tabular}

*At the significance level of $5 \%$, the critical value of correlation coefficient is 0.997 for three, and 0.950 for four repetitions.

reduce the effects of highly concentrated $\mathrm{Cl}^{-}$anion [8]. The $\mathrm{NO}_{3}{ }^{-}$anion far more increased $\mathrm{I}$ in case of the complexity with $\mathrm{Ca}^{2+}$ compared with $\mathrm{K}^{+}$(Table 3). This is probably due to the explicit favorable effect of cation $\mathrm{Ca}^{2+}$ on the increase of nitrate reductase activity in leaves [11]. At the same time, in the event of cation $\mathrm{Ca}^{2+}$ with anion $\mathrm{NO}_{3}{ }^{-}$induced the increase of I proves to be more prolonged than in case with anion $\mathrm{Cl}^{-}$(Tables 2 and 3). As known, the influence of cations and anions may cause changes in the ECP (thus affecting on only the DF parameters) and quantity of active PSII [3-5], but could reflect on the interaction between weakly associate polypeptides and membrane [12], and on the packaging of tilakoids in grana [13]. Our results confirmed that in the earlier stage of pea seedling development the mineral salts induced influence on I value mostly depended on the affects of salt concentration in solution on metabolism of plants, compared to the changes of ECP of membranes [14].

A significant reduction in $\mathrm{N}, \mathrm{N}_{\mathrm{p}}$ and $\mathrm{P}_{1}$ tomato leaves of all variants was observed in field conditions from fructification stage up to harvesting (Figure 2, Table 4). During the experiment, it was obtained that correspondence between $\mathrm{N}$ and $\mathrm{P}_{\mathrm{I}}$ changes was significant in all variants (Table 5). At the same time, in all variants a reduction in $\mathrm{N}_{P}$ reliably correlated (versus the variant 


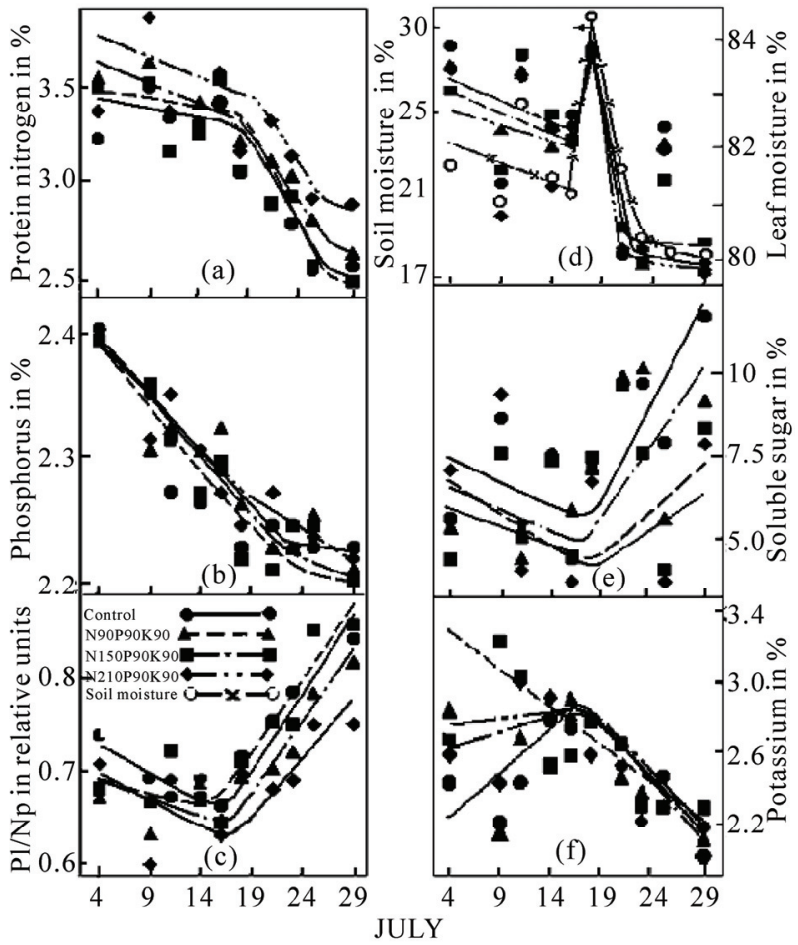

Figure 2. Temporary variation of protein nitrogen (a) and phosphorus (b) concentrations, their ratio (c), leaves and soil moistures (d), soluble sugar leaves (e) and potassium (f) amounts.

Table 4. Fertilizer dose affect on temporary variation of leaf chemical compounds quantities*.

\begin{tabular}{ccccc}
\hline \multirow{2}{*}{$\begin{array}{c}\text { Coefficient } \\
\text { Description }\end{array}$} & \multicolumn{4}{c}{ Correlation Coefficient in rel. unit } \\
\cline { 2 - 5 } & $\mathrm{N}_{0} \mathrm{P}_{0} \mathrm{~K}_{0}$ & $\mathrm{~N}_{90} \mathrm{P}_{90} \mathrm{~K}_{90}$ & $\mathrm{~N}_{150} \mathrm{P}_{90} \mathrm{~K}_{90}$ & $\mathrm{~N}_{210} \mathrm{P}_{90} \mathrm{~K}_{90}$ \\
\hline $\mathrm{r} \mathbf{N} \mathbf{T}$ & -0.880 & -0.826 & $-0,889$ & $-0,863$ \\
$\mathrm{r} \mathbf{N}_{\mathbf{p}} \mathbf{T}$ & -0.854 & -0.866 & -0.885 & -0.747 \\
$\mathrm{r} \mathbf{P}_{\mathbf{l}} \mathbf{T}$ & -0.860 & -0.920 & -0.904 & -0.930 \\
$\mathrm{r}\left(\mathbf{P}_{\mathbf{l}} / \mathbf{N}_{\mathbf{p}}\right) \mathbf{T}$ & 0.728 & 0.768 & 0.806 & 0.531 \\
$\mathrm{r} \mathbf{S}_{\mathbf{l}} \mathbf{T}$ & 0.765 & 0.561 & 0.368 & -0.014 \\
$\mathrm{r}\left(\mathbf{S}_{\mathbf{l}} / \mathbf{N}_{\mathbf{p}}\right) \mathbf{T}$ & 0.797 & 0.742 & 0.605 & 0.195 \\
$\mathrm{r} \mathbf{K}_{\mathbf{l}} \mathbf{T}$ & -0.227 & -0.512 & -0.732 & -0.606 \\
$\mathrm{r} \mathbf{K}_{\mathbf{l}} / \mathbf{N}_{\mathbf{p}} \mathbf{T}$ & 0.556 & 0.289 & 0.166 & -0.094 \\
$\mathrm{r} \mathbf{M}_{\mathbf{l}} \mathbf{T}$ & -0.640 & -0.711 & -0.668 & -0.570 \\
$\mathrm{~b} \mathbf{N} / \mathbf{T}$ & 0.774 & 0.683 & 0.796 & 0.745 \\
$\mathrm{~b} \mathbf{N}_{\mathbf{p}} / \mathbf{T}$ & -0.038 & -0.036 & -0.043 & -0.028 \\
$\mathrm{~b} \mathbf{K}_{\mathbf{l}} / \mathbf{T}$ & -6.46 & -13.73 & -17.67 & -17.16 \\
$\mathrm{~b}\left(\mathbf{P}_{\mathbf{l}} / \mathbf{N}_{\mathbf{p}}\right) / \mathbf{T}$ & 0.007 & 0.006 & 0.009 & 0.003 \\
$\mathrm{~b} \mathbf{M}_{\mathbf{l}} / \mathbf{T}$ & -0.139 & -0.150 & -0.128 & -0.123 \\
\hline
\end{tabular}

*The concentration of chemical compounds of leaves were measured at the beginning of fructification, per 10 dates. At the significance level of $5 \%$, the critical value of correlation coefficient is 0.632 .
Table 5. Fertilizer dose affect on correlative correspondence between concentrations of chemical compounds*.

\begin{tabular}{ccccc}
\hline \multirow{2}{*}{$\begin{array}{c}\text { Coefficient } \\
\text { Description }\end{array}$} & \multicolumn{4}{c}{ Correlation Coefficient in rel. unit } \\
\cline { 2 - 5 } & $\mathrm{N}_{0} \mathrm{P}_{0} \mathrm{~K}_{0}$ & $\mathrm{~N}_{90} \mathrm{P}_{90} \mathrm{~K}_{90}$ & $\mathrm{~N}_{150} \mathrm{P}_{90} \mathrm{~K}_{90}$ & $\mathrm{~N}_{210} \mathrm{P}_{90} \mathrm{~K}_{90}$ \\
\hline $\mathbf{r} \mathbf{N}_{\mathbf{p}} \mathbf{N}$ & 0.885 & 0.853 & 0.845 & 0.439 \\
$\mathbf{r N}_{\mathbf{p}} \mathbf{M}_{\mathbf{l}}$ & 0.497 & 0.545 & 0.521 & 0.153 \\
$\mathbf{r N} \mathbf{M}_{\mathbf{l}}$ & 0.553 & 0.655 & 0.614 & 0.740 \\
$\mathbf{r} \mathbf{N P}_{\mathbf{l}}$ & 0.707 & 0.691 & 0.892 & 0.731 \\
$\mathbf{r} \mathbf{N}_{\mathbf{p}} \mathbf{P}_{\mathbf{l}}$ & 0.633 & 0.783 & 0.798 & 0.560 \\
$\mathbf{r N}_{\mathbf{p}} \mathbf{K}_{\mathbf{l}}$ & 0.357 & 0.527 & 0.650 & 0.442 \\
$\mathbf{r} \mathbf{N}_{\mathbf{p}}\left(\mathbf{P}_{\mathbf{l}} / \mathbf{N}_{\mathbf{p}}\right)$ & -0.950 & -0.970 & -0.968 & -0.946 \\
$\mathbf{r M}_{\mathbf{l}} \mathbf{M}_{\mathbf{s}}$ & 0.613 & 0.656 & 0.768 & 0.798 \\
\hline
\end{tabular}

*Experimental design of data measurements was as in Table 4. At the significance level of $5 \%$, the critical value of correlation coefficient is 0.632 .

$\left.\mathrm{N}_{210} \mathrm{P}_{90} \mathrm{~K}_{90}\right)$ with $\mathrm{N}$ and $\mathrm{P}_{1}$ decrease $\left(\mathrm{d}_{\mathbf{P l ~ N p}}=61-64 \%\right.$, Figures 2(a) and 2(b), Table 5). It was previously shown that ATF, synthesised in LR, is used in phosphorylation reactions of monosaccharides at first priority [15]. Besides, a reduced mineral part of $P_{1}$ was observed in leaves, resulting from this reaction. In this case, the efficiency of phosphorylation fell significantly, inducing $\mathrm{ADF} / \mathrm{ATF}$ ratio increase. As a result, it led to the inhibition of protein synthesis $[16,17]$. During the experiment, in case of $N_{p}$ and $P_{1}$ reduction a significant $P_{1} / N_{p}$ ratio increase was obtained in all variants, except for variants $\mathrm{N}_{210} \mathrm{P}_{90} \mathrm{~K}_{90}$ (Figure 2(c), Table 4). Simultaneously, during the experiment, $\mathrm{P}_{1} / \mathrm{N}_{\mathrm{p}}$ ratio growth was reliable correspondence with $\mathrm{N}_{\mathrm{p}}$ reduction in all variants. Thus, the $\mathrm{N}_{\mathrm{p}}$ decrease could be induced only by the deficiency in $\mathrm{P}_{1}$ mineral part.

The $\mathrm{N}$ and $\mathrm{N}_{\mathrm{P}}$ reduction degree was higher particularly in the unfertilized $\mathrm{N}_{0} \mathrm{P}_{0} \mathrm{~K}_{0}$ variant and high-yield variants $\mathrm{N}_{150} \mathrm{P}_{90} \mathrm{~K}_{90}$, compared with other variants of the second group (Tables $\mathbf{4}$ and 7 ). Only first group variants showed a deficiency in reliable correspondence between the changes $\mathrm{N}$ and $\mathrm{M}_{1}$ (Table 5). The existence of correspondence between the nitrogen amount in leaves and fruits and the lack of correspondence between the applied dose of nitrogen fertilizer with concentrations $\mathrm{N}, \mathrm{N}_{\mathrm{p}}$ and $\mathrm{N}_{\mathrm{f}}$ were also obtained (Tables 6 and 7). This allows to assume that the quantity of added nitrogen fertilizer and the amount of leaf nonprotein nitrogen have not generally determined $\mathrm{N}_{\mathrm{p}}$ differences between variants. The degree of $\mathrm{N}_{\mathrm{p}}$ regression decrease was lowerest for $\mathrm{N}_{210} \mathrm{P}_{90} \mathrm{~K}_{90}$ variant (Table 4) (which has integrated with a high concentration of $\mathrm{N}$ and $\mathrm{N}_{\mathrm{f}}$ and absence of reliable changes of $\mathrm{M}_{1}$ and ratio $\mathrm{P}_{1} / \mathrm{N}_{\mathrm{p}}$, as well as correspondence between $\mathrm{N}$ and $\mathrm{N}_{\mathrm{p}}$ changes, compared with other variants (Tables 4-7)) that could, presumably, be caused by 
Table 6. Effect of fertilizer dose on average concentration and quantities of leaves chemical components*.

\begin{tabular}{|c|c|c|c|c|c|c|c|c|c|c|c|c|}
\hline \multirow{2}{*}{ Doze } & \multicolumn{7}{|c|}{ Concentration in $\%$} & \multicolumn{3}{|c|}{$\begin{array}{c}\text { Ratio of Amounts in rel. } \\
\text { unit }\end{array}$} & \multicolumn{2}{|c|}{$\begin{array}{c}\text { Total Quantity in rel. } \\
\text { unit }\end{array}$} \\
\hline & $\mathrm{N}$ & $\mathrm{N}_{\mathrm{p}}$ & $\mathrm{S}_{1}$ & St & $\mathrm{P}_{1}$ & $\mathrm{~K}_{1}$ & $\mathrm{M}_{1}$ & $\mathrm{~S}_{\mathrm{l}} / \mathrm{N}_{\mathrm{p}}$ & $\mathrm{P}_{1} / \mathrm{N}_{\mathrm{p}}$ & $\mathrm{K}_{\mathrm{l}} / \mathrm{N}_{\mathrm{p}}$ & $\mathrm{N}_{\mathrm{p} \text {-total }}$ & $\mathrm{St}_{\text {total }}$ \\
\hline $\mathrm{N}_{0} \mathrm{P}_{0} \mathrm{~K}_{0}$ & 3.65 & 3.07 & 7.82 & 5.73 & 2.254 & 2.47 & 81.75 & 2.63 & 0.741 & 0.812 & 43.4405 & 110.65 \\
\hline $\mathrm{N}_{90} \mathrm{P}_{90} \mathrm{~K}_{90}$ & 3.89 & 3.22 & 7.28 & 4.95 & 2.264 & 2.52 & 81.66 & 2.31 & 0.709 & 0.785 & 51.3912 & 116.19 \\
\hline $\mathrm{N}_{150} \mathrm{P}_{90} \mathrm{~K}_{90}$ & 3.85 & 3.10 & 6.62 & 4.84 & 2.255 & 2.64 & 81.63 & 2.19 & 0.736 & 0.856 & 72.284 & 156.5 \\
\hline $\mathrm{N}_{210} \mathrm{P}_{90} \mathrm{~K}_{90}$ & 3.95 & 3.30 & 6.74 & 3.95 & 2.265 & 2.57 & 81.36 & 2.05 & 0.690 & 0.781 & 68.607 & 140.12 \\
\hline $\mathrm{LSD}_{05}$ & 0.19 & 0.09 & 0.96 & 0.97 & 0.022 & 0.20 & 0.33 & 0.35 & 0.024 & 0.067 & & \\
\hline
\end{tabular}

*Experimental design of data measurements was as in Table 4.

Table 7. Effect of fertilizer dose on tomato fruit average chemical components concentrations, total square of leaves surface and yield*.

\begin{tabular}{|c|c|c|c|c|c|c|c|c|c|c|}
\hline \multirow{2}{*}{ Doze } & \multicolumn{5}{|c|}{ Quantity in $\%$ of dry weight } & \multirow{2}{*}{$\begin{array}{l}\text { Assimilation } \\
\text { area in } \\
\text { sq. } \mathrm{m}\end{array}$} & \multirow{2}{*}{$\begin{array}{c}\text { Yield in } \\
\text { centner per } \\
\text { ha }\end{array}$} & \multirow{2}{*}{$\begin{array}{l}\text { Yield per assimilation } \\
\text { area unit in rel. unit }\end{array}$} & \multirow{2}{*}{$\begin{array}{l}\mathbf{S}_{\text {total }} \text { in } \\
\text { rel. unit }\end{array}$} & \multirow{2}{*}{$\begin{array}{c}\mathbf{S}_{\text {total }} / \mathrm{A} \\
\text { in rel. } \\
\text { unit }\end{array}$} \\
\hline & $\mathrm{N}_{\mathrm{f}}$ & $P_{f}$ & $\mathrm{~S}_{\mathrm{f}}$ & $\mathrm{K}_{\mathrm{f}}$ & VitC & & & & & \\
\hline $\mathrm{N}_{0} \mathrm{P}_{0} \mathrm{~K}_{0}$ & 4.46 & 1.02 & 53.71 & 5.54 & 3.587 & 14.15 & 445.6 & 31.491 & 23933 & 1691 \\
\hline $\mathrm{N}_{90} \mathrm{P}_{90} \mathrm{~K}_{90}$ & 4.89 & 1.28 & 60.94 & 7.38 & 4.457 & 15.96 & 510.6 & 31.992 & 31116 & 1950 \\
\hline $\mathrm{N}_{150} \mathrm{P}_{90} \mathrm{~K}_{90}$ & 4.84 & 1.5 & 58.64 & 8.00 & 4.648 & 23.64 & 598.9 & 25.334 & 35119 & 1486 \\
\hline $\mathrm{N}_{210} \mathrm{P}_{90} \mathrm{~K}_{90}$ & 5.34 & 1.15 & 64.33 & 8.16 & 4.292 & 20.79 & 559.0 & 26.888 & 35960 & 1730 \\
\hline $\mathrm{LSD}_{05}$ & 0.76 & 0.43 & 8.24 & 2.85 & 1.02 & 5.28 & 42.7 & & & \\
\hline
\end{tabular}

*Experimental design of data measurements was as in Table 4.

an increased dose of nitrogen fertilizer. It was previously shown that an inhibition of carbohydrate synthesis and an activation of synthesis of amino acids was caused at a high nitrogen amount (similar to the mentioned variant (Tables 5 and 6)) [18]. It was also detected that the activation of nitrate reductase was significantly affected by the intensity of metabolically active mineral nitrogen inflow to the leaf, which increased as the nitrate dose growth in soil $[19,20]$.

Earlier it was showed also that in the case of $\mathrm{M}_{\mathrm{s}}$ deficit, inhibition of protein synthesis and a reduction in $\mathrm{N}_{\mathrm{p}}$, as well as an increase in $\mathrm{N}$ were observed [21-23]. During the experiment a significant $\mathrm{M}_{1}$ decrease was obtained among leaves of variants (apart from the variant $\mathrm{N}_{210} \mathrm{P}_{90} \mathrm{~K}_{90}$ ), which, however, had a significant correlation with the changes of $\mathrm{M}_{\mathrm{S}}$ in only fertilized variants $\left(\mathrm{d}_{\text {MI Ms }}=59-64 \%\right)($ Figure 2(d), Table 5). In case of the increase in the nitrogen fertilizer dose $\mathrm{M}_{1}$ determinacy from $\mathrm{M}_{\mathrm{s}}$ change was also raised. However, in all variants the reduction of $\mathrm{N}_{\mathrm{p}}, \mathrm{N}$ and nonprotein nitrogen did not reliably correlate with $\mathrm{M}_{\mathrm{s}}$ change. Significant correspondence between $\mathrm{N}$ and $\mathrm{M}_{1}$ values was registered only in second group variants of $\mathrm{N}_{90} \mathrm{P}_{90} \mathrm{~K}_{90}$ and $\mathrm{N}_{210} \mathrm{P}_{90} \mathrm{~K}_{90}$ (Table 5). This shows that the $M_{s}$ and $M_{1}$ could not be regarded as key factors causing $\mathrm{N}_{\mathrm{p}}$ reduction, as well as $\mathrm{P}_{1}, \mathrm{~K}_{1}$ and $\mathrm{S}_{1}$ changes also did not depend generally on the $\mathrm{M}_{\mathrm{S}}$ changes (Figure 2). At the same time, in variant
$\mathrm{N}_{90} \mathrm{P}_{90} \mathrm{~K}_{90}$, showing the highest degree of $\mathrm{M}_{1}$ reduction (Table 4), a reliable correspondence between changes of $S_{1}$ and ratio $S_{1} / N_{p}$ with $M_{1}$ could be induced as a result of significant correlations of both $\mathrm{N}, \mathrm{P}_{1}$ with $\mathrm{M}_{1}$ changes, peculiar only to this variant (Tables 5 and 8 ). This results show that watering plants on July 19 could be only a trigger mechanism promoting substantial changes in metabolism of plants (Figure 2).

It was obtained that the productivity Y/A of variants was decreasing in comparison with the increase in nitrogen fertilizer dose and in reliable correspondence with the $\mathrm{S}_{\mathrm{l}} / \mathrm{N}_{\mathrm{p}}$ changes (Tables 7 and $\mathbf{8}$ ). At the same time, the $\mathrm{S}_{\text {total }}$ was increasing in parallel with the enhanced dose of nitrogen fertilizers and significantly correlated with the reduced concentration of $\mathrm{S}_{1}$ (Figure 2(e), Tables $\mathbf{7}$ and 8). Consequently, the $\mathrm{S}_{1}$ accumulation reduction in variants was caused by the increase in requirement of assimilates by fruits. However, in $\mathrm{N}_{0} \mathrm{P}_{0} \mathrm{~K}_{0}$ variant, which had lower productivity, and in $\mathrm{N}_{150} \mathrm{P}_{90} \mathrm{~K}_{9}$ variant, which had higher productivity, the total accumulation of soluble sugars in fruits per unit of $A\left(S_{\text {total }} / A\right)$ was less, as compared with the second group of two other variants (Table 6). It was obtained that these two groups of variants had differences by their $\mathrm{N}_{\mathrm{p}}, \mathrm{P}_{\mathrm{l}}, \mathrm{P}_{\mathrm{l}} / \mathrm{N}_{\mathrm{p}}, \mathrm{S}_{\mathrm{l}} / \mathrm{N}_{\mathrm{p}}, \mathrm{K}_{\mathrm{l}} / \mathrm{N}_{\mathrm{p}}, \mathrm{N}_{\mathrm{f}}$, and $\mathrm{S}_{\mathrm{f}}$ (Tables 6 and 7). These results are consistent with previous findings that the nitrogen fertilizer, effect on yield growth was achieved mostly due influence on the assimi- 
Table 8. Correlation Correspondences between Tomato Average Quantities of Chemical Compounds, DF Parameters and Yield*

\begin{tabular}{|c|c|c|c|c|c|}
\hline $\begin{array}{l}\text { Coefficient } \\
\text { Description } \\
\text { (leaf) }\end{array}$ & $\begin{array}{l}\text { Correlation Coefficient } \\
\text { in rel. units }\end{array}$ & $\begin{array}{l}\text { Coefficient } \\
\text { Description } \\
\text { (leaf-fruits) }\end{array}$ & $\begin{array}{l}\text { Correlation } \\
\text { Coefficient in } \\
\text { rel. units }\end{array}$ & $\begin{array}{l}\text { Coefficient } \\
\text { Description } \\
\text { (with yield) }\end{array}$ & $\begin{array}{l}\text { Correlation } \\
\text { Coefficient } \\
\text { in rel. units }\end{array}$ \\
\hline $\mathrm{rN}_{\mathrm{p}} \mathbf{M}_{\mathrm{l}}$ & 0.841 & $\mathrm{rN} \mathbf{N}_{\mathrm{f}}$ & 0.929 & $\mathrm{rAY}$ & 0.950 \\
\hline $\mathrm{rN}_{\mathrm{p}} \mathbf{P}_{1}$ & 0.970 & $r \mathbf{N}_{p} \mathbf{N}_{\mathrm{f}}$ & 0.909 & $\mathrm{rS}_{\mathbf{l}} \mathbf{Y}$ & -0.987 \\
\hline$r K_{l} S_{l}$ & 0.946 & $\mathrm{rN}_{\mathrm{p}} \mathbf{S}_{\mathbf{f}}$ & 0.937 & $r \mathbf{K}_{1} \mathbf{Y}$ & 0.982 \\
\hline $\mathrm{r} \mathbf{S}_{\mathbf{l}} \mathbf{M}_{\mathbf{l}}$ & 0.876 & $\mathrm{rK}_{\mathrm{I}}$ vit $\mathrm{C}$ & 0.975 & $\mathrm{rN}_{\mathbf{p}} \mathbf{Y}$ & 0.304 \\
\hline $\mathrm{rSt} \mathbf{M}_{\mathbf{l}}$ & 0.963 & $\mathrm{rN}_{\mathrm{p}} \mathbf{S}_{\text {total }}$ & 0.604 & rIY & 0.454 \\
\hline $\mathrm{rI} \tau$ & 0.780 & r $\mathbf{S}_{\mathbf{l}} \mathbf{S}_{\text {total }}$ & -0.977 & $\mathrm{rS}_{\mathbf{l}} \mathbf{A}$ & 0.957 \\
\hline rI N & -0.829 & rSt $\mathbf{S}_{\text {total }}$ & 0.896 & $\mathrm{rN}_{\mathrm{p}} \mathbf{A}$ & 0.175 \\
\hline $\mathrm{rII} \mathbf{N}_{\mathrm{p}}$ & -0.941 & $\mathbf{r I S}_{\mathbf{f}}$ & 0.929 & $\mathrm{rS}_{\mathrm{I}} \mathbf{Y} / \mathbf{A}$ & 0.886 \\
\hline rI $S_{1}$ & 0.829 & $\mathrm{r} \tau \mathbf{S}_{\mathrm{f}}$ & 0.767 & $\mathrm{r} \mathbf{S}_{\mathbf{l}} / \mathbf{N}_{\mathbf{p}} \mathbf{Y} / \mathbf{A}$ & 0.962 \\
\hline rI $P_{1}$ & 0.831 & $\mathrm{rIN}_{\mathrm{f}}$ & -0.971 & $\mathrm{rSt} \mathbf{Y} / \mathbf{A}$ & -0.915 \\
\hline $\mathrm{rI} \mathbf{M}_{\mathbf{l}}$ & 0.974 & $\mathrm{rI} \mathbf{S}_{\text {total }}$ & 0.739 & $\mathrm{rN}_{\mathrm{p}} \mathbf{Y} / \mathbf{A}$ & -0.110 \\
\hline $\mathrm{r} \tau \mathbf{N}_{\mathrm{p}}$ & 0.574 & $\mathrm{r} \boldsymbol{\tau} \mathbf{S}_{\text {total }}$ & 0.925 & $\mathrm{r} \mathbf{S}_{\text {total }} \mathbf{Y}$ & 0.943 \\
\hline $\mathrm{r} \tau \mathrm{S}_{\mathrm{l}}$ & 0.929 & & & $\mathrm{r} \tau \mathbf{Y}$ & 0.864 \\
\hline rI $K_{l}$ & -0.302 & & & $\mathrm{r} \tau \mathbf{A}$ & 0.877 \\
\hline $\mathrm{r} \mathbf{I}_{\text {total }} \mathbf{K}_{\mathbf{l}}$ & 0.985 & & & $\mathrm{r} \mathbf{I}_{\text {total }} \mathbf{Y}$ & 0.939 \\
\hline $\mathrm{rI}_{\text {total }} \mathbf{S}_{\text {total }}$ & 0.780 & & & & \\
\hline
\end{tabular}

*Experimental design of data measurements was as in tables 4 and 7. At the significance level of $5 \%$, the critical value of correlation coefficient is 0.950 .

lating surface square increase [24].

During the experiment, I reduction was registered in all fertilized variants (Figure 3(a), Table 9) and substantially correlated with the $\mathrm{N}$ decrease (apart from $\mathrm{N}_{90} \mathrm{P}_{90} \mathrm{~K}_{90}$ variant) (Table 9). I reduction reliably correlated with $\mathrm{N}_{p}$ decrease in variants of the first group $-\mathrm{N}_{0} \mathrm{P}_{0} \mathrm{~K}_{0}$ and $\mathrm{N}_{150} \mathrm{P}_{90} \mathrm{~K}_{90}$ (Table 9), the average ratios of I and $\mathrm{I} / \mathrm{N}_{\mathrm{p}}$ of which were higher (Figures 3(a) and (b), Table 10) as well as $\mathrm{N}_{\mathrm{p}}$ and $\mathrm{S}_{\text {total }} / \mathrm{A}$ lower (Table 6) compared to the second group of variants. In the mean time, in the course of the experiment only the first group variants showed a reliable $\mathrm{I} / \mathrm{N}_{\mathrm{p}}$ ratio growth, which was reliable correlated with $\mathrm{N}_{\mathrm{p}}$ decrease (Figure 3(b), Table 9). According to the chemical kinetics laws, the reduction in concentration of interacting centers, as well as the decrease in efficiency of LR products used in DR (as a result of ribulose-1,5diphosphate carboxylase concentration reduction) should lessen the effectiveness of coupling of LR and DR and increase of the back reaction probability between $\mathrm{QA}^{-}$and $\mathrm{Z}^{+}$. Thus must promote certain growth of counter interaction between primary photo-oxides and photo-reducing products. Is it possible that high levels of first group I generally determined decrease coupling between LR and DR compared to the second group?

Over and above, it should be pointed out that $\mathrm{Y}$ did not significantly correspond with concentrations $\mathrm{N}$ and $\mathrm{N}_{\mathrm{p}}$ (Table 8). That is why the amount of average values of I variants was not significantly correspondent with $\mathrm{Y}$ (Table 8). Taking into account the fact that I indicates the activity of PSII reactions per unit of $\mathrm{A}$, a calculation

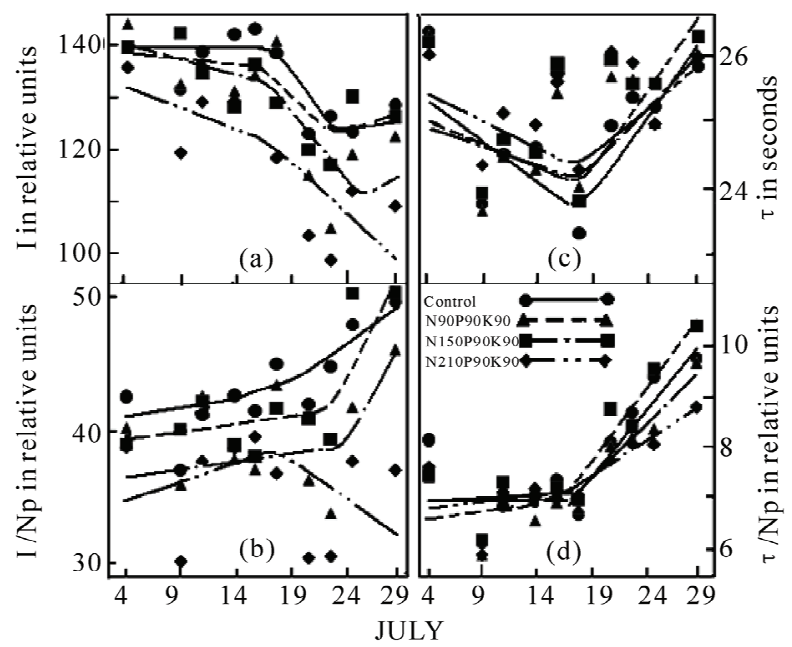

Figure 3. Temporary variation of maximal amplitude of leaf delayed fluorescence (a), $\mathrm{I} / \mathrm{N}_{\mathrm{p}}$ ratio (b), DF amplitude half decrease time (c) and $\tau / \mathrm{N}_{\mathrm{p}}$ ratio (d). 
Table 9. Temporary variation of DF parameters' and fertilizer dose affect on correlative correspondence between DF parameters' and concentrations of chemical compounds*.

\begin{tabular}{|c|c|c|c|c|}
\hline \multirow{2}{*}{$\begin{array}{l}\text { Coefficient } \\
\text { Description }\end{array}$} & \multicolumn{4}{|c|}{ Correlation Coefficient in rel. units } \\
\hline & $\mathrm{N}_{0} \mathrm{P}_{0} \mathrm{~K}_{0}$ & $\mathrm{~N}_{90} \mathrm{P}_{90} \mathrm{~K}_{90}$ & $\mathrm{~N}_{150} \mathrm{P}_{90} \mathrm{~K}_{90}$ & $\mathrm{~N}_{210} \mathrm{P}_{90} \mathrm{~K}_{90}$ \\
\hline rIT & -0.625 & -0.729 & -0.712 & -0.669 \\
\hline $\mathrm{r}\left(\mathbf{I} / \mathbf{N}_{\mathrm{p}}\right) \mathbf{T}$ & 0.780 & 0.227 & 0.675 & -0.148 \\
\hline $\mathrm{r} \tau \mathbf{T}$ & 0.118 & 0.262 & 0.327 & 0.233 \\
\hline $\mathrm{r}\left(\boldsymbol{\tau} / \mathbf{N}_{\mathrm{p}}\right) \mathbf{T}$ & 0.702 & 0.765 & 0.820 & 0.708 \\
\hline rIN & 0.779 & 0.567 & 0.823 & 0.797 \\
\hline $\mathrm{rIN}_{\mathrm{p}}$ & 0.756 & 0.595 & 0.655 & 0.498 \\
\hline $\mathrm{r}(\mathbf{I} / \mathbf{N p}) \mathbf{N p}$ & -0.885 & -0.507 & -0.847 & -0.216 \\
\hline $\mathrm{r} \boldsymbol{\tau} \mathbf{N}$ & -0.293 & -0.668 & -0.286 & -0.343 \\
\hline $\mathrm{r} \boldsymbol{\tau} \mathbf{N}_{\mathrm{p}}$ & -0.302 & -0.323 & -0.314 & -0.276 \\
\hline rIP $P_{1}$ & 0.368 & 0.781 & 0.796 & 0.610 \\
\hline r (I/Np)(P//Np) & 0.802 & 0.626 & 0.923 & 0.420 \\
\hline $\mathrm{r} \tau \mathbf{P}_{1}$ & 0.235 & -0.077 & -0.112 & 0.003 \\
\hline $\mathrm{r}(\boldsymbol{\tau} / \mathbf{N p})\left(\mathbf{P}_{/} / \mathbf{N p}\right)$ & 0.906 & 0.897 & 0.922 & 0.852 \\
\hline $\mathbf{r I M}_{\mathbf{l}}$ & 0.708 & 0.879 & 0.582 & 0.672 \\
\hline $\mathbf{r} \tau \mathbf{M}_{\mathbf{l}}$ & -0.175 & -0.468 & -0.510 & -0.390 \\
\hline $\mathrm{r} \tau \mathrm{S}_{\mathrm{I}}$ & -0.016 & 0.224 & -0.147 & 0.115 \\
\hline $\mathrm{rIK}_{\mathbf{l}}$ & 0.497 & 0.600 & 0.662 & 0.711 \\
\hline $\mathrm{r} \tau \mathbf{K}_{\mathbf{l}}$ & -0.507 & 0.085 & -0.638 & -0.201 \\
\hline $\mathrm{r}(\boldsymbol{\tau} / \mathbf{N p}) \mathbf{K}_{\mathbf{l}}$ & -0.451 & -0.401 & -0.767 & -0.504 \\
\hline $\mathrm{rI} \tau$ & -0.103 & -0.275 & -0.298 & -0.189 \\
\hline bIT & -0.630 & -1.174 & -0.733 & -1.216 \\
\hline $\mathrm{b}\left(\mathbf{I} / \mathbf{N}_{\mathbf{p}}\right) \mathbf{T}$ & 0.351 & 0.112 & 0.384 & -0.070 \\
\hline $\mathrm{b} \tau \mathbf{T}$ & 0.0143 & 0.0304 & 0.0387 & 0.0204 \\
\hline $\mathrm{b}\left(\boldsymbol{\tau} / \mathbf{N}_{\mathbf{p}}\right) \mathbf{T}$ & 0.0572 & 0.0565 & 0.0728 & 0.0381 \\
\hline $\mathrm{b} \mathbf{I} \mathbf{N}_{\mathrm{p}}$ & 17,15 & 22.59 & 13.99 & 24.46 \\
\hline $\mathrm{bI} \mathbf{M}_{\mathbf{l}}$ & 3.3059 & 6.727 & 3.1207 & 5.6734 \\
\hline
\end{tabular}

*Experimental design was as in Table 4. At the 5\% significance level the critical value of the correlation coefficient is 0.632 .

was made for total I produced by all PSII of A per variants (Table 10). In this case $\mathrm{I}_{\text {total }}$ of variants highly determined their $\mathrm{Y}\left(\mathrm{d}_{\text {Itotal }} \mathbf{Y}=88.2 \%\right)$ and simultaneously significantly correlated with average $\mathrm{K}_{1}$ values (Table 8). On the other hand, average $\mathrm{K}_{1}$ did not significant affect the changes of I average levels per unit of assimilating surface between the variants (Table 8). These results allowed to exclude the general influence of $\mathrm{K}_{1}$ on $\mathrm{I}$ as
Table 10. Fertilizer dose influence on tomato DF parameters average values*.

\begin{tabular}{cccccc}
\hline Doze & $\begin{array}{c}\mathrm{I} \text { in } \\
\text { rel.units }\end{array}$ & $\begin{array}{c}\tau \text { in } \\
\text { seconds }\end{array}$ & $\mathrm{I} / \mathrm{N}_{\mathrm{p}}$ & $\tau / \mathrm{N}_{\mathrm{p}}$ & $\begin{array}{c}\mathrm{I}_{\text {total }} \text { in rel. } \\
\text { units }\end{array}$ \\
\hline $\mathrm{N}_{0} \mathrm{P}_{0} \mathrm{~K}_{0}$ & 133.1 & 23.90 & 43.68 & 7.90 & 1883.365 \\
$\mathrm{~N}_{90} \mathrm{P}_{90} \mathrm{~K}_{90}$ & 127.9 & 24.06 & 39.91 & 7.56 & 2041.284 \\
$\mathrm{~N}_{150} \mathrm{P}_{90} \mathrm{~K}_{90}$ & 130.1 & 24.42 & 42.39 & 8.02 & 3075.564 \\
$\mathrm{~N}_{210} \mathrm{P}_{90} \mathrm{~K}_{90}$ & 119.3 & 24.60 & 36.23 & 7.52 & 2480.247 \\
$\mathrm{LSD}_{05}$ & 5.7 & 0.48 & 2.47 & 0.32 &
\end{tabular}

*Experimental design of data measurements was as in Table 4.

direct result of $\mathrm{K}_{1}$ induced changes on an ECP of chloroplast membrane. Despite it during the experiment a significant correspondence was obtained between $\mathrm{I}$ and $\mathrm{K}_{\mathrm{I}}$ changes in $\mathrm{N}_{150} \mathrm{P}_{90} \mathrm{~K}_{90}$ and $\mathrm{N}_{210} \mathrm{P}_{90} \mathrm{~K}_{90}$ variants (Table 9). A significant decreasing of $K_{1}$ in leaves was obtained exclusively for variant $\mathrm{N}_{150} \mathrm{P}_{90} \mathrm{~K}_{90}$ (Figure 2(f), Table 4), which reliably correlated with the $\mathrm{N}_{\mathrm{p}}$ reduction again in only this variant (Table 5), depending, presumably, on higher $\mathrm{K}_{1}$ amount among variants at the initial period of the experiment (Figure 2(f)). It may stimulate an intensive carbohydrate metabolism and assimilate transport in the earlier period, versus other variants. As it is well known, the increase of $\mathrm{K}_{1}$ promotes the phloem transport raising [24]. These factors could cause accelerated senescence of $\mathrm{N}_{150} \mathrm{P}_{90} \mathrm{~K}_{90}$ variant, proved also by the VitC accumulation degree in fruits of variants (Tables 6 and 7). Significant correlation between average values of $K_{1}$ and $\mathrm{VitC}$ was also registered between variants (Tables 6, 8 and 10). It is well known that VitC increase in $\mathrm{Y}$ correlated with intensive decrease of $\mathrm{N}_{\mathrm{p}}$ in senescent leaves $[15,25]$. Consequently, the binding force between $\mathrm{I}_{\text {total }}$ and $\mathrm{K}_{1}$ was, generally, stipulated by the $\mathrm{K}_{1}$ affect on metabolism of plants. On the other hand, the high values of I in first group variants, compared to second group of variants, could not result solely from the decrease coupling between LR and DR generally due to dark reaction productivity deactivation, since in case of elimination of photosynthetic efficiency influence per unit of A, a reliable dependence on the I increase persisted in case of $\mathrm{N}_{\mathrm{p}}$ reduction $\left(\mathbf{r I N}_{\mathbf{p}}\left(\mathbf{S}_{\text {total }} / \mathbf{A}\right)=-0.995, \mathbf{r I N}_{\mathbf{p}}(\mathbf{Y} / \mathbf{A})=-0.981\right)$. This shows that the high average values of $I$ in variants could principally stipulate a high concentration of active PSII per unit of A.

During the experiment, the difference in $\mathrm{N}_{\mathrm{p}}$ between two groups of variants was visualized as well by the fact that in the first group variants of $\mathrm{N}_{0} \mathrm{P}_{0} \mathrm{~K}_{0}$ and $\mathrm{N}_{150} \mathrm{P}_{90} \mathrm{~K}_{90}$ registered lower values of I regression coefficient and a significant increase $I / N_{p}$ in concurrently higher $N_{p}$ regression coefficient, versus the second group variants (Tables 4 and 9). The similar changes of $I / N_{p}$ in variants (Table 9), confirmed that $\mathrm{N}_{\mathrm{p}}$ reduction was probably caused generally by carbohydrate metabolism enzyme 
quantity decrease, because as previously reported, at the end of the vegetation $\mathrm{N}_{\mathrm{p}}$ decrease is basically caused by the reduction in ribulose-1,5-diphosphate carboxylase amount, leading also to a reduction of photosynthesis intensity [21,26-29]. Furthermore, the fact that the changes in phosphate status have only small effect on the photochemical apparatus of leaves was also previously confirmed [30]. Our data also shows that in case of nitrogen fertilizer affect the total concentration of LR centers is likely to constitute a negative feedback with $\mathrm{Y}$ of variants per unit of assimilating surface square $\left(\mathbf{r I}_{\text {total }} \mathbf{Y} / \mathbf{A}=\right.$ $-0.944)$.

Theoretically, it was assumed that the $\tau$ (Figure 1), in general, depended on the activation of phosphorylation reaction of sugars in Calvin cycle, which led to proton gradient reduction as a result of ATP use and described the intensity of LR and DR of photosynthesis coupling [4-6]. The obtained results showed that the $\tau$ values of variants were not in significant correspondence with $N_{p}$, $\mathrm{M}_{1}, \mathrm{~S}_{\mathrm{l}}$, but in contrast to I, were determined mostly by the level of carbohydrate metabolism end products per unit of $\mathrm{A}\left(\mathrm{R}_{\tau(\text { Stotal/A } \mathrm{St})}=1.000\right)$ (Figure 3(c), Table 8). The average values $\tau$ of variants were highly determined by the $S_{\text {total }}$ in fruits $\left(d_{\tau \text { Stotal }}=85.6 \%\right)$ (Tables $\left.7,8,10\right)$. This is why in the event of elimination of effect of starch formation processes the values $\tau$ significantly correlated with quantity of $\mathrm{S}_{\text {total }}\left(\mathrm{r}_{\tau \text { Stotal }(\mathrm{St})}=-0,997\right)$, which was generally determined by the $\mathrm{Y}$ of variants (Table 8), being previously caused by the reliable binding force $r_{\tau}$ $\mathbf{Y} / \mathbf{A}(\mathbf{S t})=-0.995$. Besides, in case of the increase $S_{\text {total }}$, a significant reduction in $S_{1}$ and $S_{t}$ raise in leaves was registered between variants (Table 8). This clearly shows the interaction between the $\mathrm{Y}$ formation and the photosynthetic production process in leaves and its affect on $\tau$ values.

Thus, I and $\tau$ parameters of tomato variants were stipulated substantially by different key factors. Therefore, there was not a reliable correspondence between their average values (Table 8) and within those parameters in the stages of fructification up to harvesting (Table 9). During the experiment, reduction in LR/DR coupling efficiency in case of $\mathrm{N}_{p}$ decrease was confirmed by the increase in ratio $\tau / N_{p}$ and its reliable correlation with ratio $P_{1} / N_{p}$ changes in all variants (Figure 3(d), Table 9), as well as by the fact that in the first group with a low protein amount (Table 4 ), the average $\tau / \mathrm{N}_{\mathrm{p}}$ ratio was higher compared to the second group variants (Table 10). However, it is important to point out that during the experiment significant increases of $\tau$ was showed only per unit of $\mathrm{Np}$ and, on the other hand, temporal significance change of $\tau$ of variants was not obtained (Table 9). This could be caused by $\tau$ high dependence on carbohydrate metabolism end products accumulation in fruits.

The data also shows that during the experiment I decrease generally correlates with $\mathrm{M}_{1}$ reduction of variants
(Table 9), which appears to be the key generator for reliable correlation between their averaged values (Table 8). It is well known that nitrogen fertilization affects on the osmotic adjustment of tomato plants [31]. Water deficit stimulated both leaf relative water amount decrease, osmotic potential, as well as increase in glycinebetaine and sugar leaf amounts [32]. Simultaneously, a marked increase in electrolyte leakage, decrease in amounts of chlorophylls a and b, and inhibition of PSII activity were observed. Thus, the previously analysis data showed that the amounts of major PSII proteins, including D1 and D2 proteins in PSII reaction centre and light-harvesting Chl $a / b$-protein complex (LHC2) in periphery, declined in case of water stress increasing $[33,34]$. Therefore, it is possible that $\mathrm{M}_{1}$ changes were not a key factor stipulating degradation of the main part of $\mathrm{N}_{\mathrm{p}}$ pool (Table 5), but in case of PSII, had their own input in deactivation of those centers. Indeed, in case of elimination of $\mathrm{M}_{1}$ affect on $I$ the binding force between $I$ and $N_{p}$ was increased, I also reliably determined changes of both $\mathrm{N}_{p}$ and $\mathrm{M}_{1}\left(\mathrm{rIN}_{\mathrm{p}}\left(\mathbf{M}_{\mathrm{l}}\right)=-0.995, \mathrm{RI}\left(\mathrm{N}_{\mathrm{p}} \mathbf{M}_{\mathrm{l}}\right)=1.000\right)$. In that event, during the experiment, the high degree of I reduction especially in second group variants of $\mathrm{N}_{90} \mathrm{P}_{90} \mathrm{~K}_{90}$ and $\mathrm{N}_{210} \mathrm{P}_{90} \mathrm{~K}_{90}$ (Figure 3(a), Table 9) was determined by water stress influence increase as a result of higher concentrations of $\mathrm{N}$ compared with plants of first group variants (Table 6) and more intensive $\mathrm{M}_{1}$ reduction in $\mathrm{N}_{90} \mathrm{P}_{90} \mathrm{~K}_{90}$ variant (Table 4). This assumption is also confirmed by the significant correlation between $\mathrm{N}$ and $\mathrm{M}_{1}$, which is obtained only in second group of variants (Table 5). Previously, it was shown that in case of dehydration of cut-off leaves of potato both I growth and $\tau$ reduction were seen at the initial stage, which was caused by the influence of osmotic or ionic potentials on an ECP change [35]. This study showed that more than $3.2-3.8 \%$ leaf moisture loss induced I reduction resulting from PSII deactivation. In the present experiment on tomato, the differences between average initial and end levels of $\mathrm{M}_{1}$ variants are 4\% (apart form the variant $\mathrm{N}_{150} \mathrm{P}_{90} \mathrm{~K}_{90}$ (around 3\%)) (Figure 2(d)). Therefore, this assumption has certain reasons. Some input in I reduction via changes of ionic potential during water loss which may be caused by the disturbance of interaction between weakly associated proteins and membranes in a case of salt concentration increase [12] or through explicit effects of osmotic potential on genetic apparatus was possibly made in vivo moisture decrease (northern hybridization indicated that progressive water stress remarkably reduced amounts of the chloroplast gene $p s b A$ and $p s b D$ and nuclear gene $c a b$ transcripts) [34]).

It is well known that in a number of events the level of $\mathrm{Y}$ may be stipulated by the resistance of metabolism and photosynthetic apparatus toward unfavourable environmental impacts [7,36,37]. Therefore, the next experiment was carried out to study the potato production processes 
in the period between bud and harvesting stages. The resistance of plants to drought was modified by various doses of phosphorus and potash fertilizers in water deficit conditions (Table 11). During this experiment, it was observed that $\mathrm{P}_{1}$ concentration did not depend on $\mathrm{P}_{\mathrm{s}}$, so $\mathrm{N}$ was determined by phosphorus amount in leaves and soil $\left(R \mathbf{N}\left(\mathbf{P}_{\mathbf{l}} \mathbf{P}_{\mathbf{s}}\right)=0.974\right)$ (Tables 11 and 12). Besides, $N$ concentration increased in case of $\mathrm{P}_{\mathrm{s}}$ amount growth $\left(\mathrm{rNP}_{\mathrm{s}}\left(\mathrm{P}_{1}\right)=0.955\right)$, and, in contrast, during $\mathrm{P}_{1}$ increase, $\mathrm{N}$ amount reduced accordingly $\left(\mathrm{rNP}_{\mathbf{l}}\left(\mathbf{P}_{\mathbf{s}}\right)=0.968\right)$. At the same time, $\mathrm{K}_{\mathrm{s}}$ increment reliably increased $\mathrm{K}_{1}$, which significantly correlated with $\mathrm{P}_{1}$ increase (Table 12).

$\mathrm{P}_{120-150}$ doses are heightening for potato plants [9]. In case of such doses, a decrease in drought resistance of plants and yield falls were obtained [7,22,23,36], which probably depended on the decrease in free water concentration in cells [31,37]. The above-mentioned is also proved by I dependence on the dose of phosphorus anion in nutrient medium (Table 1). Previous studies have proved that water deficit induced the $\mathrm{N}$ increase that accompanied with $\mathrm{N}_{\mathrm{p}}$ reduction as a result of inhibition of protein synthesis [22,23]. Evidently, these were dominant cause for productivity decrease in potato variants of $\mathrm{N}_{150} \mathrm{P}_{120} \mathrm{~K}_{45}$ and $\mathrm{N}_{150} \mathrm{P}_{120} \mathrm{~K}_{60}$, showing increased $\mathrm{N}$ (Table 11). As described previously $K_{s}$ stimulates increase of photophosphorylation efficiency, assimilates transport intensity and nitrogen metabolism $[6,25,38]$. In addition, it was assumed that the favourable effects of $\mathrm{K}_{1}$ on plants in droughty conditions may be promoted via affection on exchange of cytoplasmic $\mathrm{K}^{+}$and $\mathrm{H}^{+}$cations of stroma [39]. Generally, while eliminating the effects of leaves moisture changes caused by the unfavourable impact of increased $\mathrm{P}_{\mathrm{s}}$ doses on plants, the $\mathrm{K}_{\mathrm{s}}$ increase significant correlated with the $\mathrm{N}$ decrease $\left(\mathrm{rNK}_{\mathrm{S}}\left(\mathbf{M}_{\mathbf{l}}\right)=\right.$ $-0.906)$. This result confirmed that the increased dose of potash fertilizer induced optimization of nitrogen metabolism, and drought resistance enhancement among variants. A further proof of this was also the increased $\mathrm{P}_{1}$ amount and yield (Tables 11 and 12). This assumes harmony with previously studies results [38].

In the end of vegetation it was obtained that both I and $\tau$ values of potato variants were highly determined by $\mathrm{N}$ $\left(\mathrm{d}_{\mathrm{IN}}=87.6 \%, \mathrm{~d}_{\tau \mathrm{N}}=76.0 \%\right)$, so the values of both DF parameters reliably correlated (Table 12), as opposed to the experiment on tomato (Table 8). In the meantime, the I of variants was substantially growing, and the $\tau$ was reliably decreasing in case of $\mathrm{K}_{\mathrm{s}}$ increase (Table 12). The average values of both $\mathrm{I}$ and $\tau$ values of variants significantly correlated and each of these parameters reliably correlated with the Y of variants (also, as opposed to the experiment on tomato variants) (Table 12). As known, in droughty conditions PSII deactivation and electron transport inhibition were confirmed [40,41]. Although the positive correlation between I and Y of variants indicated that the $\mathrm{Y}$ increase mostly depended on nitrogen metabolism optimization, which probably resulted in the increase of photosynthesis primary reaction centers concentration.

\section{CONCLUSIONS}

The raised quantity of potash fertilizer induced increase in the efficiency of nitrogen fertilizers effect resulted by enhancement of protein production $\left(r \mathbf{K}_{\mathbf{l}} \mathbf{N}_{\text {p-total }}=0.954\right)$, ripening $\mathrm{A}\left(\mathrm{rN}_{\mathrm{p} \text {-total }} \mathbf{A}=0.985, \mathrm{rK}_{1} \mathrm{~A}=0.983\right), \mathrm{Y}$ $\left(r \mathbf{N}_{\text {p-total }} \mathbf{Y}=0.973, \mathrm{rK}_{\mathbf{I}} \mathbf{Y}=0.982\right)$ and the total amount of starch accumulated in leaves $\left(\mathbf{r N}_{\mathbf{p} \text {-total }} \mathbf{S t}_{\text {total }}=0,970, \mathbf{r} \mathbf{K}_{\mathbf{l}}\right.$ $\left.\mathbf{S t}_{\text {total }}=0,979\right)$ of tomato plants. However, nitrogen fertilizer induced falling of the yield per unit of A $\left(\mathrm{rN}_{\text {p-total }} \mathbf{Y} / . \mathbf{A}\right.$ $=-0.952)$. Besides, $K_{1}$ had a significant impact on the yield generation per unit of $\mathrm{A}\left(\mathrm{r} \mathbf{K}_{\mathbf{I}} \mathbf{Y} / \mathbf{A}=-0.915\right)$.

Generally, accumulation of soluble sugars in tomato fruits determined $\mathrm{Y}$ of variants, however, total $\mathrm{N}_{\mathrm{p}}$ and $\mathrm{K}_{1}$ of plant did not significantly correlate with the $\mathrm{S}_{\text {total }}$ and the efficiency of its formation per unit of A $\left(\mathrm{r} \mathbf{N}_{\mathrm{p} \text {-total }} \mathbf{S}_{\text {total }}\right.$ $=0.933, \mathbf{r N}_{\text {p-total }} \mathbf{S}_{\text {total }} / \mathbf{A}=-0.549, \mathbf{r K}_{\mathbf{l}} \mathbf{S}_{\text {total }}=0.863, \mathbf{r K}_{\mathbf{l}}$ $\left.\mathbf{S}_{\text {total }} / \mathbf{A}_{\mathbf{A}}=-0.615\right)$. As for potato, the data shows that in

Table 11. Fertilizer doze affect on chemical components quantities, yield and DF parametres of potato*.

\begin{tabular}{|c|c|c|c|c|c|c|c|c|c|c|c|}
\hline \multirow{2}{*}{$\begin{array}{l}\text { Fertilizer } \\
\text { Doze }\end{array}$} & \multicolumn{4}{|c|}{$\begin{array}{l}\text { Quantity in leaves in } \% \text { of } \\
\text { dry weight }\end{array}$} & \multicolumn{2}{|c|}{$\begin{array}{l}\text { Quantity in soil in } \\
\% \text { of dry weight }\end{array}$} & \multirow{2}{*}{$\begin{array}{c}\text { Yield in } \\
\text { centner per } \\
\text { ha }\end{array}$} & \multicolumn{2}{|c|}{ I in rel. units } & \multicolumn{2}{|c|}{$\tau$ in seconds } \\
\hline & $\mathrm{N}$ & $\mathrm{P}_{1}$ & $\mathrm{~K}_{\mathrm{l}}$ & $\mathrm{M}_{1}$ & $\mathrm{P}_{\mathrm{s}}$ & $\mathrm{K}_{\mathrm{s}}$ & & $\mathrm{I}_{\text {average }}$ & $\mathrm{I}_{\mathrm{end}}$ & $\tau_{\text {average }}$ & $\tau_{\text {end }}$ \\
\hline $\mathrm{N}_{0} \mathrm{P}_{0} \mathrm{~K}_{0}$ & 0.28 & 0.28 & 5.7 & 83.7 & 67.4 & 108.2 & 256.3 & 95.91 & $73.1 \pm 2.4$ & 21.9 & $17.28 \pm 1.26$ \\
\hline $\mathrm{N}_{150} \mathrm{P}_{90} \mathrm{~K}_{45}$ & 0.28 & 0.30 & 5.9 & 79.6 & 69.2 & 112.3 & 316.9 & 110.87 & $80.1 \pm 3.2$ & 20.16 & $15.36 \pm 1.62$ \\
\hline $\mathrm{N}_{150} \mathrm{P}_{120} \mathrm{~K}_{60}$ & 0.34 & 0.25 & 5.6 & 81.0 & 65.6 & 110.2 & 305.3 & 112.17 & $75.0 \pm 3.2$ & 19.56 & $15.9 \pm 1.38$ \\
\hline $\mathrm{N}_{150} \mathrm{P}_{150} \mathrm{~K}_{75}$ & 0.28 & 0.30 & 6.2 & 81.5 & 68.0 & 113.4 & 339.8 & 112.91 & $75.73 \pm 3.7$ & 18.96 & $14.88 \pm 1.02$ \\
\hline $\mathrm{N}_{150} \mathrm{P}_{120} \mathrm{~K}_{45}$ & 0.84 & 0.25 & 5.4 & 79.0 & 69.4 & 106.1 & 294.7 & 102.33 & $61.18 \pm 3.13$ & 21.36 & $19.5 \pm 1.44$ \\
\hline
\end{tabular}

*The leaf DF parameters of leaves were measured since bud stage, per 5 dates, and concentration of chemical compounds of leaves and soil at the end of vegetation. The deviation of average values of DF parameters' did not exceed 3-5\% of its average value. 
Table 12. Correlative correspondence between chemical compounds amounts in leaves and soil, DF parameters' and yield of potato*.

\begin{tabular}{|c|c|c|c|}
\hline $\begin{array}{l}\text { Coefficient } \\
\text { Description } \\
\text { (leaves) }\end{array}$ & $\begin{array}{l}\text { Correlation } \\
\text { coefficient } \\
\text { In rel. units }\end{array}$ & $\begin{array}{c}\text { Coefficient } \\
\text { Description } \\
\text { (leaves-fruits-yeild) }\end{array}$ & $\begin{array}{l}\text { Correlation } \\
\text { coefficient } \\
\text { In rel. units }\end{array}$ \\
\hline $\mathrm{rN} \mathbf{M}_{\mathbf{l}}$ & -0.608 & $\mathrm{r} \mathbf{N}_{\mathrm{p}} \mathbf{P}_{\mathrm{s}}$ & 0.457 \\
\hline $\mathrm{rN} \mathbf{P}_{1}$ & -0.655 & $\mathrm{r} \mathbf{P}_{1} \mathbf{P}_{\mathrm{s}}$ & 0.339 \\
\hline $\mathrm{rN} \mathbf{K}_{\mathbf{l}}$ & -0.706 & $\mathrm{r} \mathbf{K}_{\mathbf{l}} \mathbf{K}_{\mathrm{s}}$ & 0.910 \\
\hline $\mathrm{rK}_{\mathbf{l}} \mathbf{P}_{\mathbf{l}}$ & 0.888 & $\mathrm{rN} \mathbf{P}_{\mathbf{s}}$ & 0.457 \\
\hline$r \mathbf{P}_{1} \mathbf{M}_{1}$ & 0.223 & $\mathrm{rN} \mathrm{K} \mathbf{K}_{\mathrm{s}}$ & -0.754 \\
\hline $\mathrm{rK} \mathbf{M}_{\mathrm{l}}$ & 0.260 & $\mathrm{rP}_{\mathbf{l}} \mathbf{K}_{\mathrm{s}}$ & 0.757 \\
\hline rI N & -0.936 & $\mathrm{rM}_{\mathbf{l}} \mathbf{P}_{\mathrm{s}}$ & -0.540 \\
\hline $\mathrm{r} \boldsymbol{\tau} \mathbf{N}$ & 0.872 & rI $K_{s}$ & 0.927 \\
\hline $\mathrm{rI} \tau$ & -0.929 & $\mathrm{r} \tau \mathbf{K}_{\mathrm{s}}$ & -0.966 \\
\hline rI K $K_{1}$ & 0.629 & $\mathrm{rI} \mathbf{P}_{\mathrm{s}}$ & -0.294 \\
\hline $\mathrm{r} \tau \mathbf{K}_{\mathbf{l}}$ & 0.838 & $\mathbf{r} \mathbf{I}_{\text {average }} \mathbf{Y}$ & 0.915 \\
\hline rI $\mathbf{P}_{1}$ & 0.690 & $\mathrm{r} \boldsymbol{\tau}_{\text {average }} \mathbf{Y}$ & -0.902 \\
\hline r $\mathbf{I}_{\text {average }} \boldsymbol{\tau}_{\text {average }}$ & -0.909 & & \\
\hline
\end{tabular}

*Experimental design of data measurements was as in table 11. At the significance level of $5 \%$, the critical value of correlation coefficient is 0.950 .

frames of moisture deficit, aggravated and implemented by unbalanced increased doses of phosphorus fertilizer, the optimization of metabolism and yield of variants were ensured by the increase in potash fertilizer dose.

During both field experiments, I mostly depended on the activity of nitrogen metabolism and probably determined changes of active PSII concentrations per unit of A. The amounts of I average values of variants did not have a significant correlation with $\mathrm{Y}$ for tomato plants, as their productivity did not depend from $\mathrm{N}_{\mathrm{p}}$ and on production process intensity per unit of A. Simultaneously, total I from full A of tomato plant significant correlated with the productivity of variants (Table 8). In case of potato, the production process mostly depended on the degree of water deficit influence on plants' through affect on nitrogen metabolism, thus leading to the correlation between I and $\tau$ as well as their both correspondence with $\mathrm{Y}$ of variants as opposed to tomato experiment.

It was observed that the values $\tau$ predominantly depended on the level of carbohydrate metabolism in the whole plant system, including the quantity of its end products, therefore resulting in correlation with $\mathrm{Y}$ of both tomato and potato variants as opposed to their I.

Thus, the results showed that the DF parameters are closely intertwined with metabolism and formation of yield. This is a biological base triggering the use of these parameters in system analysis of production process. The combined use of the both DF parameters allows generating complete information about key affects on the production process. Fast measurement of DF parameters, the availability of portable devices designed for this goal, as well as the possibility of saving of resources and time versus the chemical-analytical method, allow to recommend the use of DF parameters for the system analyses of production process and the diagnosis of physiological state of plants.

\section{ACKNOWLEDGEMENTS}

Thanks to Drs L.P. Gorbunova, G.A .Gabrielyan, K.V. Stepanyan for assistance in chemical analyses.

\section{REFERENCES}

[1] Mar, T., Brehlner and J., Roy, G. (1975) Induction kinetics of delayed light emission in spinach chloroplasts. Biochimica et Biophysica Acta, 376, 345-353.

[2] Wraight, C. A., Crofts, A. R. (1971) Delayed fluorescence and the high-energy state of chloroplast. European Journal of Biochemistry, 19, 386-397.

[3] Malkin, S. (1977) Delayed luminescence. In: Barber, J. Ed., Primary Processes of Photosynthesis, Elsevier, Amsterdam, 349-431.

[4] Goltsev, V., Zaharieva, I., Lambrev, P., Yordanov, I. and Strasser, R. (2003) Simultaneous analyses of prompt and delayed chlorophyll a fluorescence in leaves during the induction period of dark to light adaptation. Journal of Theoretical Biology, 225, 171-183.

[5] Goltsev, V., Chernev, P., Zaharieva, I., Lambrev, P. and Strasser, R. J. (2005) Kinetics of delayed chlorophyll a fluorescence registered in milliseconds time range. Photosynthesis Research, 84, 209-215.

[6] Matorin, D. N., Venedictov, P. S., Timofeev, K. N. and Rubin, A. B. (1978) Research of delayed fluorescence induction curves of green plants. Russian Scientific Report of High School. Biological Sciences, 2, 35-41.

[7] Peterburgskiy, A. V. (1976) Practical work of agrochemistry.

[8] Gurbickiy, Z. I. (1963) Physiological and agronomical base for using fertilizers. Academy of Science, Moscow.

[9] Peterburgskiy, A. V., Asarov, C. K. and Pleshkov, B. P. (1964) Agrochemistry.

[10] Mrah, S., Ouergh, Z., Eymery, F., Rey, P., Hajji, M., Grignon, C. and Lachaal, M. (2006) Efficiency of biochemical protection against toxic effects of accumulated salt differentiates Thellungiella halophila from Arabidopsis thaliana. Journal of Plant Physiology, 164, 375-384.

[11] Davidian, J. C. and Salsac, L. (1979) Interaction anions-cations $\left(\mathrm{Ca}^{2+}, \mathrm{K}^{+}, \mathrm{NO}_{3}^{-}, \mathrm{Cl}^{-}\right)$et influence sur induction de l'activity nitrate reductase dans les raciness excises de maize. Physiology Vegetable, 17, 375-385.

[12] Avagyan, A. B., Venedictov, P. S., Dobrecov, G.. E., Rubin, A. B. (1983) Influence of uni- and divalent cations on interaction ANS and rodamin $6 \mathrm{~g}$ fluorescent probes with chloroplasts. Biological Sciences, 5, 33-36. 
[13] Barber, J. (1982) Influence of surface charges on thylakoid structure and function. Annual Review of Plant Physiology, 33, 261-268.

[14] Avagyan, A. B. (1988) Influence of mineral salts on leaves delayed fluorescence. Biological Journal of Armenia, 41, 487-492.

[15] Brivare, V. N., Nimbacar, J. D. and Chavan, P. D. (1987) Products of ${ }^{14} \mathrm{CO}_{2}$ labelling in senescent leaves of French bean. Photosynthetica, 21, 360-362.

[16] Plant, Z., Mayoral, M. L. and Reinold, L. (1987) Effect of altered sink-source ratio on photosynthetic metabolism of source leaves. Plant Physiology, 85, 786-791.

[17] Woodrow, I. E. (1986) Control of the rate of the photosynthetic carbon fixation. Biochimica et Biophysica Acta, 851, 181-192.

[18] Mohamed, A. H. and Graham, A. A. (1979) Possible mechanism of ammonium regulation of photosynthetic carbon flow in higher plants. Plant Physiology, 64, 263-268.

[19] Ingemarson, B. (1987) Nitrogen utilization in Lemma. I. Relations between net nitrate flux, nitrate reduction and in vivo activity and stability of nitrate reductase. Plant Physiology, 85, 856-859.

[20] Shander, D. L. and Boyer, J. S. (1976) Nitrate reductase activity in maize leaves II. Regulation by nitrate flux at low leaf potential. Plant Physiology, 58, 505-509.

[21] Bertamini, M., Zulini, L., Muthuchelian. K., Nedunchezhian, N. (2006) Effect of water deficit on photosynthetic and other physiological responses in grapevine (Vitis vinifera L. cv. Riesling) plants. Photosynthetica, 44, 51-54.

[22] Isikeev II. (1985) Mineral nutrition and irrigation influence on proteins and noncontiguous amino acids amounts in cereal grass. Russian Agrochemystry, 10, 78-91.

[23] Vodianic, A. S., Vodianic, T. M. (1984) About pea overhead organs nitrogen metabolism in case of unfavorable moistering condition. Russian Agricultural Biology, 10, 12-15.

[24] Hunt, E. R., Weber, J. A., Gates, D. M. (1985) Effects of nitrate application on Amarantus powelii wats. Plant Physiology, 79, 619-624.

[25] Maharashtra, D. (1999) Quality aspects of k nutrition in horticultural crops. In: Imas, P. Ed., Recent trends in $n u-$ trition management in horticultural crops. International Potash Institute, Israel. http://www.ipipotash.org/presen tn/qaknhc.html

[26] Peterson, L. W. and Huffaker, R. C. (1975) Loss of ribulose-1, 5-diphosphate carboxylase and increase in proteolytic activity during senescence barley leaves. Plant Physiology, 55, 1109-1015.

[27] Wittenbach, V. A. (1979) Ribolose biphosphat carboxylase and proteollytic activity in wheat leaves from anthesis through senescence. Plant Physiology, 64, 884-887.
[28] Friedrich, J. W., Huffaker, R. C. (1980) Photosynthesis, leaf resistance and ribolose-1,5-biphosphate carboxylase degradation in senescing barley leaves. Plant Physiology, 65, 1103-1007.

[29] Mae, T. N., Kay, N., Makino, A. and Ohira, K. (1984) Relation between ribulose biphosphate carboxylase content and chloroplast number in naturally senescing primary leaves of wheat. Plant Cell Physiology, 25, 333336.

[30] Abadia, J., Rao, M. and Terry, N. (1987) Changes in leaf phosphate status have only small effect on the photo chemical apparatus of sugar beet leaves. Plant Science, 50, 49-55.

[31] García, A. L., Fuentes, V. and Gallego, J. (1996) Influence of nitrogen supply on osmoregulation in tomato ( $L y$ copersicon esculentum Mill.) plants under moderate water stress. Plant Science, 115, 33-38.

[32] Martìnez, J. P., Lutts, S., Schanck, A., Bajji, M. and Kinet, J. M. (2004) Is osmotic adjustment required for water stress resistance in the Mediterranean shrub Atriplex halimus L. Journal of Plant Physiology, 161, 1041-1051.

[33] Gaspar, L., Sarvari, E., Molnar, I., Stehli, L., MolnarLang, M., Galiba, G. (2002) Structural changes of the photosynthetic apparatus under osmotic stress in different Triticum aestivum and Aegilops biuncialis genotypes. Acta Biologica Szegediensis, 46, 91-93.

[34] Liu, W., Yuan, S., Zhang, N., Lei, T., Duan, H., Liang, H. and Lin, H. (2006) Effect of water stress on photosystem 2 in two wheat cultivars. Biologia Plantarum, 50, $597-$ 602.

[35] Avagyan, A. B. (1991) Study of dehydration effects on the photosynthetic apparatus of detached leaves at different temperatures by the method of delayed fluorescence. Russian Biophysics, 36, 885-890.

[36] Bacanov, N. S. (1970) Potato.

[37] Proshkin, A. V. (1973) Influence of mineral nutrition on state of water in spring wheat leaves. Biological Sciences, 4, 90-93.

[38] Abdel-Wahab, S. (1995) Potassium nitrution and nitrogen fixation by nodulated legumes. Nutrient Cycling in Agroecosystems, 8, 9-20.

[39] Pier, P. A. and Berkowitz, G. A. (1987) Modulation of water stress effects on photosynthesis by altered leaf $\mathrm{K}^{+}$. Plant Physiology, 85, 665-661.

[40] Potter, J. R. and Boyer, J. S. Chloroplast response to low leaf potentials. II. Role of osmotic potentials. Plant Physiology 1973, 51, 993-997.

[41] Powless, S. B. and Bjorkman, O. (1982) Hight light and water stress effects on photosynthesis in Nerium oleander. II. Inhibition of photosynthesis reaction under water stress: Interaction with light level. In: Carnegie Institution Year Book, 81, 76-77. 


\section{Abbreviations:}

A - total square of leaves surface of plants

DF - delayed fluorescence of chlorophyll

I - maximum amplitude of leaves DF

$\mathrm{I}_{\text {total }}$ - total I from A emitting surface

$\tau$ - time of half decrease of I

LR - light reactions of photosynthesis

$\mathrm{DR}$ - dark reactions

$\mathrm{ECP}$ - electrochemical potential

$\mathrm{r}$ - correlation coefficient

$\mathrm{b}$ - regression coefficient

$\mathrm{d}$ - determination coefficient

$\mathrm{R}$ - multiple correlation coefficient

$\mathrm{NPK}$ - added amount of fertilizers in $\mathrm{N}: \mathrm{P}_{2} \mathrm{O}_{5}: \mathrm{K}_{2} \mathrm{O}$ in $\mathrm{kg} / \mathrm{ha}$

$\mathrm{T}-$ vegetation period

$\mathrm{Y}-$ yield

$\mathrm{Y} / \mathrm{A}$ - productivity per unit of $\mathrm{A}$

$\mathrm{M}_{1}$ - leaf humidity
$\mathrm{M}_{\mathrm{s}}$ - soil humidity,

$\mathrm{N}$ - leaf nitrogen

$\mathrm{N}_{\mathrm{p}}$ - leaf protein

$\mathrm{N}_{\mathrm{f}}$ - fruit nitrogen

$\mathrm{N}_{\mathrm{p} \text {-total }}$ - total protein of leaves

$\mathrm{P}_{1}$ - leaf phosphorus

$\mathrm{P}_{\mathrm{f}}-$ fruit phosphorus

$\mathrm{P}_{\mathrm{s}}-$ soil phosphorus

$\mathrm{K}_{1}$ - leaf potassium

$\mathrm{K}_{\mathrm{f}}$ - fruit potassium

$\mathrm{K}_{\mathrm{s}}$ - soil potassium

$\mathrm{S}_{1}-$ leaf soluble sugars

$\mathrm{S}_{\mathrm{f}}-$ fruit soluble sugars

$\mathrm{S}_{\text {total }}$ - total quantity of soluble sugars accumulated in yield $\left(\mathrm{S}_{\mathrm{f}} \times \mathrm{Y}\right)$

St - leaf starch

VitC - fruit vitamin C 